\title{
Penerepan Model Pembelajaran Problem Based Learning untuk Meningkatkan Sikap Ilmiah dan Hasil Belajar Kognitif Mahasiswa pada Mata Kuliah Ekologi Tumbuhan
}

\author{
Hadi Purwanto ${ }^{1}$, Siti Aminah ${ }^{2}$, Witri Ramadhani ${ }^{3}$, Fauzan Azim ${ }^{4}$ \\ ${ }^{1}$ Program Studi Pendidikan IPA, Universitas Muhammadiyah Riau \\ ${ }^{2} S M P$ Negeri 2 Pendalian IV Koto \\ ${ }^{3,4}$ Program Studi Pendidikan Teknik Elektronika, Universitas Mubammadiyah Riau \\ e-mail: \\ 1'hadipurwanto@umri.ac.id \\ 2sitiaminahyp@gmail.com \\ 33itrirahmadhani@umri.ac.id \\ 4fauzanazim@umri.ac.id
}

\begin{abstract}
.
This study aims to determine the increase in scientific attitudes and cognitive learning outcomes of students in plant ecology courses through the application of problem-based learning models. This research was conducted on 4D grade students of the Biology Education Study Program, FKIP Riau Islamic University. This research is a classroom action research conducted in two cycles, each cycle consisting of four stages, namely planning, implementing, observing, and reflecting. Data were collected through observation sheets and cognitive learning outcomes tests. The results of data analysis in the first and second cycles showed an increase in students' scientific attitudes by $12.03 \%$ and an increase in student absorption from the first cycle to the second cycle by $5.5 \%$ and classical completeness increased by $20 \%$ from the first cycle to the second cycle. In general, it can be concluded that the application of problem-based learning models can improve scientific attitudes and cognitive learning outcomes of 4D grade students of the Biology Education Study Program, FKIP Riau Islamic University in plant ecology courses.
\end{abstract}

Keywords: cognitive learning outcomes, scientific attitude, problem based learning model

\begin{abstract}
ABSTRAK.
Penelitian ini bertujuan untuk mengetahui peningkatan sikap ilmiah dan hasil belajar kognitif mahasiswa pada mata kuliah ekologi tumbuhan melalui penerapan model pembelajaran problem based learning. Penelitian ini dilaksanakan pada mahasiswa kelas 4D Program Studi Pendidikan Biologi FKIP Universitas Islam Riau. Penelitian ini merupakan penelitian tindakan kelas yang dilaksanakan dalam dua siklus, setiap siklus terdiri dari empat tahap yaitu perencanaan, pelaksanaan, observasi, dan refleksi. Data dikumpulkan melalui lembar observasi dan tes hasil belajar kognitif. Hasil analisis data siklus pertama dan kedua menunjukkan adanya peningkatan sikap ilmiah mahasiswa sebesar $12,03 \%$ dan daya serap mahasiswa mengalami peningkatan dari siklus pertama ke siklus kedua sebesar 5,5\% serta ketuntasan klasikal meningkat sebesar 20\% dari siklus pertama ke siklus kedua. Secara umum dapat disimpulkan bahwa penerapan model pembelajaran problem based learning dapat meningkatkan sikap ilmiah dan hasil belajar kognitif mahasiswa kelas 4D Program Studi Pendidikan Biologi FKIP Universitas Islam Riau pada mata kuliah ekologi tumbuhan.
\end{abstract}

Kata kunci: Hasil belajar kognitif, sikap ilmiah, model pembelajaran berbasis masalah 


\section{PENDAHULUAN}

Pendidikan bertujuan untuk mengembangkan potensi peserta didik agar menjadi manusia yang beriman dan bertakwa kepada Tuhan yang Maha Esa, berakhlak mulia, sehat, berilmu, cakap, kreatif, mandiri, dan menjadi warga Negara yang demokratis serta bertanggung jawab (Trianto, 2013). Dalam keseluruhan proses pendidikan, kegiatan belajar merupakan kegiatan yang paling pokok. Ini berarti bahwa berhasil tidaknya pencapaian tujuan pendidikan banyak bergantung kepada bagaimana proses belajar yang dialami oleh siswa sebagai anak didik (Slameto, 2010). Belajar diartikan sebagai proses perubahan tingkah laku pada diri individu dan individu dengan lingkungannya (Usman, 2010).

Belajar terjadi ketika ada interaksi antara individu dan lingkungan, baik lingkungan fisik maupun lingkungan sosial, lingkungan fisik adalah buku, alat peraga, dan alam sekitar sedangkan lingkungan pembelajaran adalah lingkungan yang meransang dan menantang siswa untuk belajar (Hamdani, 2011). Selanjutnya menurut Arsyad, (2013), belajar merupakan suatu proses, suatu kegiatan dan bukan suatu hasil atau tujuan. Belajar bukan hanya mengingat akan tetapi lebih luas dari pada itu, yakni mengalami. Hasil belajar bukan suatu penguasaan hasil latihan, melainkan perubahan kelakuan. Belajar merupakan perubahan tingkah laku atau penampilan dengan serangkai kegiatan misalnya membaca, mengamati, mendengarkan, meniru dan sebagainya. Juga belajar itu akan lebih baik kalau si subjek belajar itu mengalami atau melakukannya, jadi tidak bersifat verbalistik. Hal ini tidak terlepas dari peranan seorang guru yang mendidik peserta didik (Sardiman., 2012). Kemampuan yang diharapkan dapat dimiliki anak didik akan ditentukan oleh kerelevansian penggunaan suatu metode yang sesuai dengan tujuan. Itu berarti tujuan pembelajaran akan dapat dicapai dengan penggunaan metode yang tepat. Selanjutnya dikatakan bahwa metode adalah suatu cara yang digunakan untuk mencapai tujuan yang telah di tetapkan.

Guru tidak hanya dituntut menyampaikan materi pelajaran tetapi juga bisa mengaktualisasikan strateginya membentuk watak peserta didik melalui kepribadian dan nilai-nilai yang berlaku. Pada pembelajaran biologi, hasil belajar biologi merupakan salah satu indikator yang menentukan kualitas pendidikan biologi. Pembelajaran biologi bertujuan untuk mengembangkan kompetensi peserta didik, melalui pembelajaran biologi diharapkan sikap ilmiah peserta didik dapat lebih dikembangkan yang terdiri dari rasa ingin tahu, jujur, sabar, terbuka, kritis, tekun, cermat disiplin, peduli terhadap lingkungan dan bekerjasama dengan orang lain.

Perguruan Tinggi memiliki peranan yang sangat besar dalam rangka pembangunan nasional. Berdasarkan Kepmendiknas Nomor: 232/U/2000 tentang pedoman penyusunan kurikulum pendidikan tinggi dan penilaian hasil belajar mahasiswa, salah satu mata kuliah keterampilan dan keahlian cabang ilmu biologi adalah ekologi tumbuhan. Berdasarkan karakteristik pembelajaran biologi, dalam proses pembelajaran peserta didik mampu menemukan fakta-fakta, membangun konsep, teori serta sikap ilmiah sehingga meningkatkan hasil belajar peserta didik sesuai dengan indikator dan tujuan pembelajaran yang ditentukan. Cara yang digunakan bisa dengan variasi model pembelajaran. Variasi model pembelajaran merupakan aktivitas yang tersistem dari sebuah lingkungan yang terdiri dari guru dan siswa untuk saling berinteraksi dalam melakukan suatu kegiatan sehingga tujuan dalam proses pembelajaran dapat tercapai. Model inquiri, model pemecahan masalah, dan model pembelajaran langsung, merupakan variasi pembelajaran yang dapat dilakukan oleh guru (Mulyasa, 2006).

Berdasarkan hasil observasi peneliti di Program Studi Pendidikan Biologi FKIP Universitas Islam Riau, terhadap proses perkuliahan ekologi tumbuhan, penyebab menurunnya sikap ilmiah dan hasil belajar peserta didik dipengaruhi beberapa aspek yaitu, dosen sudah menggunakan berbagai model dan metode pembelajaran namun kurangnya minat peserta didik saat proses pembelajaran berlangsung menjadi permasalahan, ini terlihat dari ketika dosen menjelaskan materi terlihat peserta didik yang kurang memperhatikan. Peserta didik hanya mendengarkan, mencatat penjelasan dari dosen sehingga terlihat peserta didik kurang mau berpikir. 
Selain itu, mahasiswa juga menjadi kurang informatif, karena butuh waktu lama untuk mengkontruksikan pengetahuan. Sehingga kompetensi yang harus dicapai dalam proses pembelajaran yaitu peningkatan hasil belajar kognitif dan ketrampilan proses sikap ilmiah mahasiswa belum tercapai. Ketrampilan proses sikap ilmiah para peserta didik dalam memperoleh pengetahuan belum maksimal, karena dipengaruhi oleh beberapa faktor, diantaranya rasa ingin tahu peserta didik masih kurang. Hal ini bisa terlihat pada saat proses pembelajaran masih ada mahasiswa tidak memperhatikan dan jika kurang mengerti mengenai materi pembelajaran, mahasiswa enggan untuk bertanya.

Kedisiplinan mahasiswa masih kurang ditandai dengan tidak mematuhi jadwal belajar yang telah ditetapkan serta tidak tertib dalam menerapkan kaidah tata tulis dalam laporan tugas yang telah diberikan dosen. Sikap bekerjasama mahasiswa juga masih lemah ditandai dengan mahasiswa tidak mau ikut berpartisipasi aktif dalam kelompok belajarnya karena mahasiswa hanya mengandalkan temannya yang memiliki akademik tinggi, dalam diskusi mahasiswa juga masih belum bisa menghargai pendapat kelompok lain.

Ketelitian dan tanggung jawab peserta didik juga belum maksimal. Hal ini bisa dilihat mahasiswa enggan untuk membaca materi pada buku sumber yang lain dan saat diberikan tugas oleh dosen mahasiswa masih belum bisa menyelesaikan dengan baik. Permasalahan yang ditemukan peneliti tersebut dampaknya akan berpengaruh terhadap rendahnya hasil belajar dan sikap ilmiah peserta didik dalam perkuliahan ekologi tumbuhan. Permasalahan yang ditemukan peneliti tersebut dampaknya akan berpengaruh terhadap rendahnya hasil belajar dan sikap ilmiah peserta didik dalam perkuliahan ekologi tumbuhan. Rendahnya sikap ilmiah mahasiswa akan mempengaruhi hasil belajarnya. hal ini terlihat pada hasil belajar mahasiswa di bawah standar dari penilaan acuan patokan (PAP) yang ditentukan lulus untuk mata kuliah ekologi tumbuhan yaitu nilai 75, rata-rata nilai ulangan peserta didik dapat dilihat pada Tabel 1.

\section{Tabel 1. Persentase nilai ekologi tumbuhan mahasiswa kelas D semester IV Prodi Biologi FKIP Universitas Islam Riau.}

\begin{tabular}{ccc}
\hline Ulangan Harian & Persentase Pencapaian PAP & PAP \\
\hline UH 1 & $44,44 \%$ & 75 \\
\hline UH 2 & $57,77 \%$ & 75 \\
\hline
\end{tabular}

(Sumber: Dosen Ekologi Tumbuhan)

Hal ini menunjukkan bahwa peserta didik mengalami kesulitan dalam memahami materi, jika diberi suatu permasalahan mengenai materi perkuliahan, mahasiswa mengalami kesulitan untuk memecahkan masalah tersebut, peserta didik tidak dapat membangun konsep sendiri. Disini terlihat bahwa peserta didik dalam memperoleh pengetahuan belum mampu menerapkan ketrampilan proses sikap ilmiah yang positif dalam pembelajarannya.

Dengan demikian, dosen masih mengupayakan bagaimana peserta didik untuk membangun makna dalam diri pada prose pembelajaran. Dengan adanya permasalahan tersebut, penulis menerapkan pembelajaran biologi yang berpusat pada peserta didik, dosen sebagai fasilitator dan motivator dalam mengoptimalkan proses pembelajaran saja, harus dapat memilih suatu strategi dan model yang dapat mengaktifkan peserta didik dalam belajar sehingga dapat meningkatkan hasil belajar dan keterampilan proses sikap ilmiah.

Salah satu usaha yang dapat dilakukan peneliti adalah menerapkan model pembelajaran yang mengutamakan keterlibatan peserta didik dalam membangun pengetahuannya dan diharapkan mampu melibatkan peserta didik aktif dalam penguasaan materi dengan melihat segenap kemampuan yang dimilikinya dalam proses pembelajaran sehingga prestasi belajar peserta didik dapat meningkat. Salah satu model pembelajaran yang mengutamakan keterlibatan peserta didik dalam mengontruksi pengetahuannya serta dapat menunjang peserta didik secara aktif dalam kegiatan pembelajaran adalah model pembelajaran berbasis masalah (problem based learning). 
Menurut Rusmana (dalam Susanti, 2018) pembelajaran berbasis masalah merupakan salah satu pendekatan pembelajaran yang digunakan untuk merangsang berpikir tingkat tinggi siswa yang berorientasi pada masalah dalam dunia nyata. Adapun Moffit (dalam Rusman, 2013) mengemukakan pembelajaran berbasis masalah adalah pembelajaran yang menjadikan dunia nyata sebagai konteks untuk belajar bagaimana berpikir kritis dan berkemampuan memecahkan masalah dalam membangun konsep esensi materi pelajaran. Sehingga inti dan persamaan dua pendapat tersebut bahwa pembelajaran berbasis masalah menekankan pada kemampuan berpikir dalam proses kognitif yang melibatkan kemampuan mental dalam menghadapi permasalahan.

Penelitian lain untuk memperkuat penerapan model pembelajaran berbasis masalah dapat meningkatkan hasil belajar kognitif dan sikap ilmiah dapat dilihat berdasarkan hasil penelitian Israfiddin et al., (2016) yang menyimpulkan bahwa model problem based learning dan sikap ilmiah memberikan pengaruh positif terhadap prestasi belajar. Selanjutnya penelitian yang dilakukan oleh Ismaini et al., (2017) yang menyimpulkan bahwa model problem based learning berpengaruh secara signifikan dalam peningkatan sikap ilmiah dan hasil belajar peserta didik. Penelitian lain yang menggunakan pembelajaran berbasis masalah Aprilianti et al., (2018) yang melakukan penelitian tindakan kelas yang menunjukkan bahwa model dapat meningkatkan sikap ilmiah dan hasil belajar siswa kelas VII B SMPN 11 Kota Bengkulu. Berdasarkan hasil penelitian yang dipaparkan di atas, maka dapat disimpulkan model pembelajaran berbasis masalah dapat menjadi salah satu alternatif untuk meningkatkan sikap ilmiah dan hasil belajar kognitif mahasiswa.

\section{METODOLOGI}

Penelitian ini merupakan penelitian tindakan kelas (PTK) atau Classroom Action Research yang dilakukan untuk mengetahui pengaruh penerapan model pembelajaran berbasis masalah terhadap peningkatan hasil belajar kognitif dan sikap ilmiah mahasiswa pada mata kuliah ekologi tumbuhan. Penelitian ini dilaksanakan di kelas D semester empat Program Studi Pendidikan Biologi FKIP Universitas Islam Riau. Subjek penelitian berjumlah 36 orang mahasiswa 31 orang perempuan dan 5 orang laki-laki) dengan kemampuan kognitif heterogen. Penelitian ini dilaksanakan pada bulan Mei sampai dengan Juli. Penelitian tindakan kelas dilaksanakan dalam bentuk siklus (daur ulang) menyeluruh dan bertujuan memperbaiki praktik pembelajaran. Siklus dimulai dengan pengamatan dan perencanaan tindakan (planning), pelaksanaan tindakan (action), pengobservasian hasil tindakan, dan pelaksanaan refleksi (reflection).Teknik pengumpulan data merupakan alat yang digunakan pada waktu melaksanakan penelitian mencari dan mengumpulkan data penelitian. Pada penelitian ini pengumpulan data dilakukan dengan observasi dan tes. Instrumen yang digunakan untuk pengumpulan data adalah lembar tes dan lembar observasi.

\section{TEMUAN DAN PEMBAHASAN}

Pelaksanaan penelitian tindakan kelas terhadap sikap ilmiah dan hasil belajar kognitif mahasiswa biologi FKIP Universitas Islam Riau dilakukan dua siklus dengan jumlah pertemuan sebanyak sembilan kali pertemuan, dimana 1 kali pertemuan untuk sosialisasi dan 8 kali pertemuan untuk menerapkan pembelajaran berdasarkan masalah (Problem Based Learning). Pada pertemuan I Siklus I mahasiswa dibagi menjadi 6 kelompok besar dan dalam satu kelompok terdiri dari 5-6 orang. Pembagian kelompok berdasarkan nilai tes sebelum PTK dengan pokok bahasan yakni faktor lingkungan abiotik (Edhapis dan Klimatologis serta peranannya bagi tumbuhan). 


\section{Analisis Data Sikap Ilmiah Mahasiswa Setelah Siklus I}

Hasil analisis data sikap ilmiah mahasiswa Program Studi Pendidikan Biologi FKIP Universitas Islam Riau kelas 4D setelah menerapkan model pembelajaran problem based learning pada siklus I dapat dilihat pada Tabel 2 berikut.

Tabel 2. Rata-rata sikap ilmiah mahasiswa setelah siklus I

\begin{tabular}{clcc}
\hline No & Indikator Sikap Ilmiah & Persentase (\%) & \multicolumn{1}{c}{ Kategori } \\
\hline 1 & Rasa Ingin Tahu & 74,84 & Baik \\
\hline 2 & Disiplin & 73,36 & Baik \\
\hline 3 & Tanggung Jawab & 79,72 & Baik \\
\hline 4 & Ketelitian & 58,94 & Cukup \\
\hline 5 & Kerja Sama & 83,99 & Sangat Baik \\
\hline & Rata-rata & $\mathbf{7 4 , 3 7}$ & Baik \\
\hline
\end{tabular}

Berdasarkan Tabel 2 tentang sikap ilmiah mahasiswa Program Studi Pendidikan Biologi FKIP Universitas Islam Riau kelas 4D setelah siklus I terlihat bahwa persentase tertinggi adalah pada indikator kerja sama sebesar 83,99\% dengan kategori sangat baik. Sedangkan sikap ilmiah dengan persentase terendah adalah pada indikator ketelitian sebesar 58,94\% dengan kategori cukup. Sedangkan rata-rata sikap ilmiah mahasiswa setelah siklus I adalah sebesar 74,37\% dengan kategori baik. Perbandingan persentase sikap ilmiah mahasiswa setelah siklus I dapat dilihat pada Gambar 1

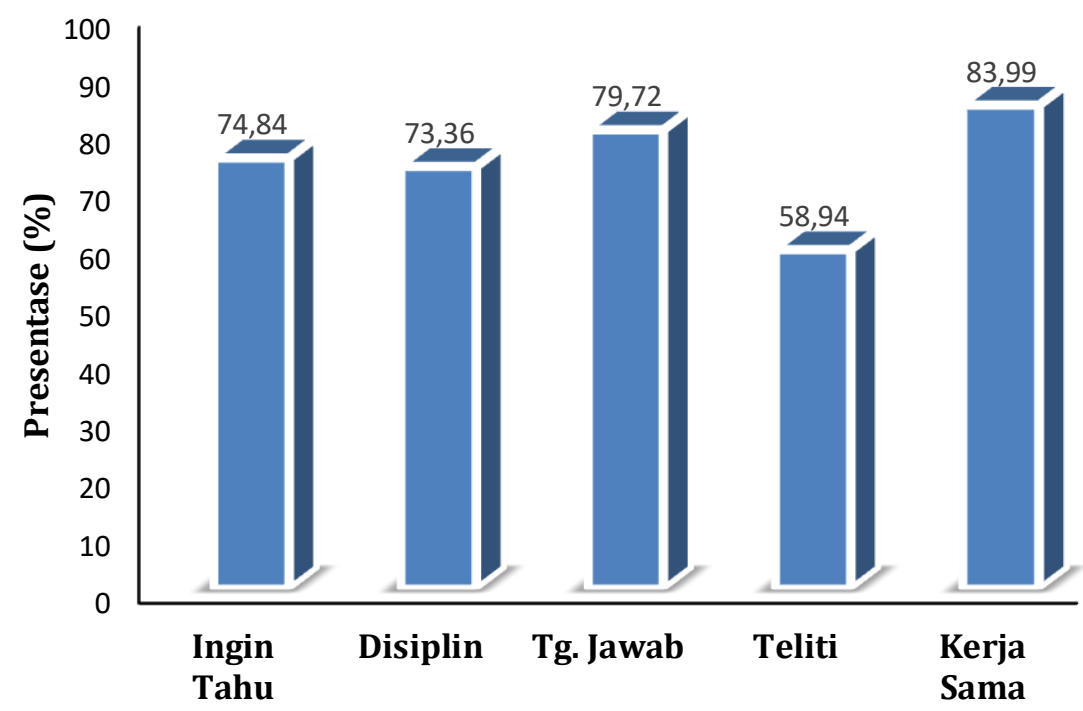

Gambar 1. Perbandingan sikap ilmiah mahasiswa tiap indikator setelah siklus I

\section{Analisis Data Hasil Belajar Kognitif Mahasiswa Siklus I}

Berdasarkan nilai kognitif yang dijelaskan di atas yaitu dari nilai kuis dan tes siklus I, maka nilai kognitif diperoleh dari 40\% rata-rata nilai kuis setiap kali pertemuan dan $60 \%$ dari hasil tes siklus I. Daya serap nilai kognitif, ketuntasan individual dan ketuntasan klasikal mahasiswa Program Studi Pendidikan Biologi FKIP Universitas Islam Riau kelas 4D pada hasil belajar kognitif di siklus I dapat dilihat pada Tabel 2 berikut 
Tabel 2. Daya serap, ketuntasan individual dan ketuntasan klasikal mahasiswa pada hasil belajar kognitif pada siklus I

\begin{tabular}{cllc}
\hline \multirow{2}{*}{ No } & \multirow{2}{*}{ Kriteria } & \multirow{2}{*}{ Kategori } & Daya Serap Kognitif Siklus I \\
\cline { 3 - 4 } & $90-100$ & Sangat Baik & Presentase (\%) \\
\hline 1 & $80-89$ & Baik & 22,85 \\
\hline 2 & $75-79$ & Cukup & 48,57 \\
\hline 3 & $66-74$ & Kurang & 57,71 \\
\hline 4 & $0-65$ & Kurang Sekali & 14,28 \\
\hline 5 & & Rata-Rata Kelas & 8,57 \\
\hline & Ketuntasan Individu & 83,12 (Sangat Baik) \\
\hline & Ketuntasan Klasikal & 26 \\
\hline
\end{tabular}

Berdasarkan Tabel 2, daya serap hasil belajar kognitif mahasiswa setelah PTK siklus I persentase yang paling banyak yaitu pada kategori cukup sebesar 48,57\% dan persentase paling sedikit berada pada kategori kurang sekali sebesar 8,57\%. Rata-rata daya serap mahasiswa nilai kognitif siklus I setelah PTK yaitu sebesar 83,12\% dengan kategori sangat baik.

Rata-rata daya serap nilai kognitif sebelum PTK adalah (70,6\%), dan rata-rata daya serap nilai kognitif pada siklus I adalah $(83,12 \%)$. Peningkatan yang terjadi pada rata-rata nilai daya serap kognitif terhadap sebelum PTK dan nilai kognitif siklus I adalah sebesar 12,52\%, peningkatan ini disebabkan karena penerapan model pembelajaran berbasis masalah. Dimana model ini dapat membuat mahasiswa terbiasa untuk pemecahkan masalah secara terampil, perbandingan daya serap kognitif sebelum PTK dan Siklus I dilihat pada Gambar 2.

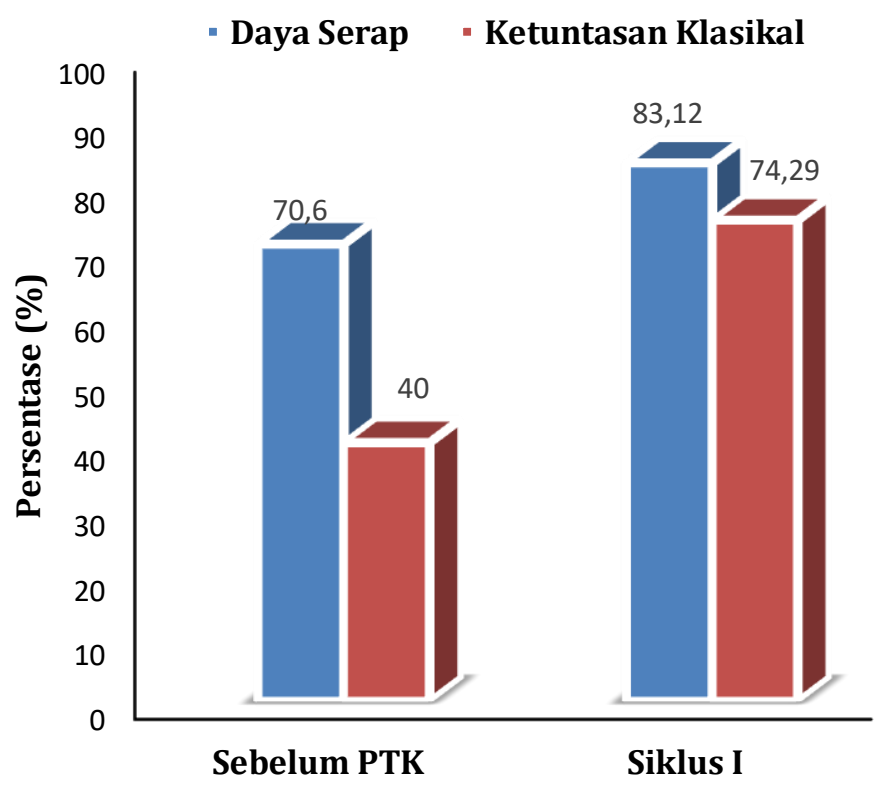

Gambar 2. Perbandingan rata-rata daya serap dan ketuntasan klasikal mahasiswa pada hasil belajar kognitif sebelum PTK dan siklus I

\section{Analisis Data Sikap Ilmiah Mahasiswa Setelah Siklus II}

Nilai rata-rata sikap ilmiah mahasiswa Program Studi Pendidikan Biologi FKIP Universitas Islam Riau kelas 4D setelah siklus II dapat dilihat pada Tabel 3 berikut 
Tabel 3. Rata-rata sikap ilmiah mahasiswa setelah siklus II

\begin{tabular}{clll}
\hline No & Indikator Sikap Ilmiah & Persentase (\%) & Kategori \\
\hline 1 & Rasa Ingin Tahu & 88,86 & Sangat Baik \\
\hline 2 & Disiplin & 92,14 & Sangat Baik \\
\hline 3 & Tg. Jawab & 94,14 & Sangat Baik \\
\hline 4 & Ketelitian & 77,71 & Sangat Baik \\
\hline 5 & Kerja Sama & 98,88 & Sangat Baik \\
\hline & Rata-rata & $\mathbf{9 0 , 3 4}$ & Sangat Baik \\
\hline
\end{tabular}

Berdasarkan Tabel 3 dapat dilihat bahwa sikap ilmiah mahasiswa setelah siklus II memiliki rata-rata 90,34\% dengan kategori sangat baik. Persentase tertinggi terdapat pada indikator kerja sama yaitu sebesar 98,88\% dengan kategori sangat baik. Hal ini menandakan bahwa mahasiswa bekerja sama dan berdiskusi mengeluarkan masing-masing pendapat untuk menyelesaikan tugastugas yang diberikan dosen. Sedangkan indikator sikap ilmiah paling rendah adalah ketelitian dengan persentase sebesar $77,71 \%$ termasuk kategori baik. Hal ini dikarenakan mahasiswa belum mampu menyelesaikan tugas-tugas yang diberikan dosen sesuai dengan prosedurnya dan masih tergesa-gesa dalam mengerjakannya. Perbandingan persentase sikap ilmiah mahasiswa setelah siklus II dapat dilihat pada Gambar 3 berikut.

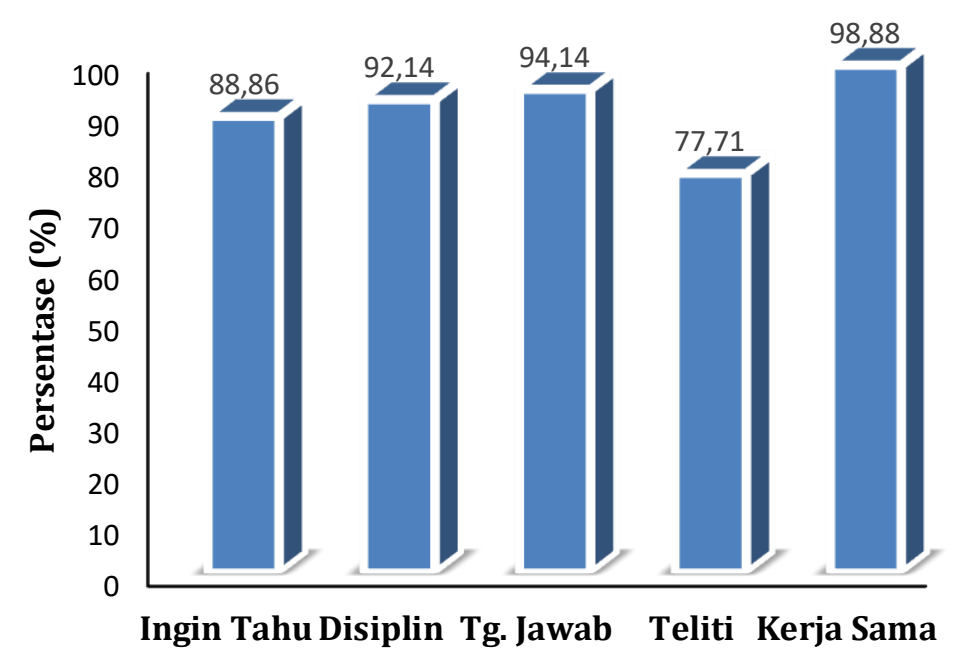

Gambar 3. Sikap ilmiah mahasiswa setiap indikator setelah siklus II

Kenaikan sikap ilmiah ini tidak terlepas karena penggunaan model pembelajaran berdasarkan masalah (Problem Based Learning) menggugah rasa ingin tahu mahasiswa. Rasa ingin tahu ini muncul akibat dari pembelajaran yang dimulai dengan pemberian isu-isu atau masalah yang menarik yang ada di sekitar mahasiswa. Selain itu, kesempatan untuk bereksplorasi diberikan secara luas untuk mencari tahu berbagai informasi berdasarkan permasalahan yang diajukan, sehingga mahasiswa aktif dalam belajar. Ketertarikan dan antusiasme mahasiswa dalam memecahkan permasalahan yang diajukan pun menjadi sangat tinggi. Antusiasme merupakan keinginan untuk mengetahui secara alami, bila pada diri mahasiswa telah ada keinginan maka mahasiswa akan memiliki motivasi belajar.

Sikap disiplin mahasiswa pada perkuliahan ekologi tumbuhan tergolong dalam kategori sangat baik. Tingginya sikap disiplin mahasiswa pada saat kuliah lapangan terlihat pada saat mahasiswa menyelesaikan tugas-tugasnya tepat waktu, tidak meninggalkan kelompok dan tidak bermain-main dalam kuliah lapangan. Sehingga memanfaatkan waktu semaksimal mungkin. Mahasiswa yang memiliki sikap disiplin pasti akan memperhitungkan waktu yang tersedia dalam menjawab pertanyaan dan dalam melaksanakan kuliah lapangan sehingga waktu yang disedikan 
dapat digunakan secara efektif. Penggunaan waktu yang efektif dapat membuat tingkat kedisiplinan yang lebih baik. Hal ini sesuai dengan pendapat Arikunto, tumbuhnya sikap kedisiplinan bukan merupakan peristiwa yang terjadi seketika. Kedisiplinan pada diri seseorang tidak dapat tumbuh tanpa tangan pendidik dan itupun dilakukan setahap demi setahap (Arikunto, 2012).

Pada indikator tanggung jawab yang menjadi acuan adalah sikap mahasiswa untuk selalu berusaha menyelesaikan tugas kelompok dengan sebaik-baiknya dan dapat mengemukakan alasan pendapat yang disampaikan.Pada tahap kuliah lapangan dan diskusi kelompok mahasiswa sudah menunjukkan bahwa sudah memiliki tanggung jawab yang baik sekali. Sobur, (2003) menyatakan bahwa baik buruknya hasil belajar ditentukan oleh kegiatan atau proses pembelajaran. Dalam proses belajar digunakan strategi belajar, metode, teknik dan model-model pembelajaran yang sesuai dengan topik dan kondisi peserta didik, maka hasil belajar juga akan lebih baik.

Sikap ketelitian mahasiswa juga sudah sangat baik, dalam kegiatan diskusi kelompok serta kuliah lapangan mahasiswa lebih teliti dalam mengerjakan tugas-tugas kelompok, dan melaksanakan kuliah lapangan sesuai prosedur yang ada serta tidak tergesa-gesa dalam menyelesaikannya.Selain itu, mahasiswa juga diberikan kesempatan bekerja sama di dalam kelompok untuk melakukan percobaan atau investigasi untuk memecahkan permasalahan yang ada. Dalam menggali informasi mahasiswa dituntut untuk bekerja semaksimal mungkin. Kegiatan ini melatih mahasiswa untuk mengembangkan sikap disiplin dan tanggung jawabnya dalam mengerjakan suatu tugas.Selain itu, mahasiswa juga dapat mengembangkan sikap kerja samanya di dalam kelompok. Mereka dapat saling bertukar pikiran dan saling memberi masukan untuk memecahkan permasalahan yang disajikan.

Terbukti dengan tingginya sikap kerja sama mahasiswa dibandingkan dengan komponen sikap ilmiah lainnya di setiap siklus yaitu $83,99 \%$ pada siklus I dan 98,89\% pada siklus II. Kegiatan kelompok sangat jelas melatihkan aktivitas mahasiswa dengan kerja sama, melakukan diskusi, mengemukakan ide masing-masing anggota kelompok dan mengajari secara bersama-sama, mahasiswa menggali sendiri seluruh informasi berkaitan dengan topik yang menjadi kajian dan mendiskusikan dengan kelompoknya.

Aspek yang diperhatikan dalam menilai sikap kerja sama mahasiswa adalah diskusi dalam kelompok serta pembagian tugas antar anggota kelompok dalam pe-laksanaan kuliah lapangan. Dalam pelaksanaan kegiatan belajar mengajar, seseorang perlu dilatih untuk bekerja sama karena ada kegiatan yang baik sekali bila dilakukan secara bersama-sama dengan prinsip sosialisasi seperti pelaksanaan kuliah lapangan (Usman, 2010).

Berdasarkan uraian di atas, terlihat bahwa model pembelajaran berdasarkan masalah (Problem Based Learning) dapat mengembangkan aspek-aspek sikap ilmiah pada diri mahasiswa karena sikap ilmiah dapat dipengaruhi oleh beberapa faktor yaitu pendidik, lingkungan belajar, konsep diri, teman dan orang tua.

\section{Analisis Data Hasil Belajar Kognitif Mahasiswa Siklus II}

Berdasarkan hasil belajar kognitif yang telah dijelaskan di atas yaitu dari nilai kuis dan Tes siklus II, maka nilai kognitif berasal dari $40 \%$ nilai kuis mahasiswa setiap kali pertemuan dan $60 \%$ dari hasil tes siklus II. Nilai kognitif siklus II, dan daya serap nilai kognitif mahasiswa Program Studi Pendidikan Biologi FKIP Universitas Islam Riau kelas 4D pada hasil belajar kognitif di siklus II dapat dilihat pada Tabel 4 berikut 
Tabel 4. Daya serap, ketuntasan individual dan ketuntasan klasikal mahasiswa pada hasil belajar kognitif di siklus II

\begin{tabular}{cllc}
\hline No & Kriteria & Kategori & $\begin{array}{c}\text { Daya Serap Kognitif } \\
\text { Siklus II }\end{array}$ \\
\cline { 3 - 4 } & & Sangat Baik & Presentase (\%) \\
\hline 1 & $90-100$ & Baik & 45,71 \\
\hline 2 & $80-89$ & Cukup & 34,28 \\
\hline 3 & $75-79$ & Kurang & 11,42 \\
\hline 4 & $66-74$ & Kurang Sekali & 8,57 \\
\hline 5 & $0-65$ & & - \\
\hline & Rata-Rata Kelas & 88.27 (Baik) \\
\hline & Ketuntasan Individu & 33 \\
\hline & Ketuntasan Klasikal & 94,29 (Tuntas) \\
\hline
\end{tabular}

Berdasarkan Tabel 4 di atas dapat dijelaskan bahwa daya serap hasil belajar nilai kognitif mahasiswa setelah PTK siklus II pada materi Ekosistem dan Suksesi. Jumlah mahasiswa yang memiliki persentase tertinggi yaitu pada kategori sangat baik sebesar $45,71 \%$ dan persentase terendah berada pada kategori kurang sekali sebesar 8,57\%. Rata-rata daya serap mahasiswa pada hasil belajar nilai kognitif siklus II setelah PTK yaitu 88,27\% dengan kategori baik dan diperoleh ketuntasan klasikal sebesar 94,29\%.

Rata-rata daya serap hasil belajar kognitif Siklus I adalah 83,12\%, dan rata-rata pada siklus II adalah $88,27 \%$. Peningkatan yang terjadi pada rata-rata nilai daya serap kognitif terhadap sebelum PTK dan nilai kognitif siklus I adalah sebesar 5,15\%, peningkatan ini disebabkan karena penerapan model pembelajaran berbasis masalah dimana model ini dapat membuat mahasiswa terbiasa untuk memecahkan maslaah secara terampil, memupuk solidaritas sosisal dengan terbiasa berdiskusi dengan teman sekelompoknya, karena ada suatu masalah harus diselesaikan melalui eksperimen hal ini membiaskan mahasiswa dalam metode eksperimen. perbandingan nilai kognitif siklus I dan siklus II dapat dilihat pada Gambar 4.

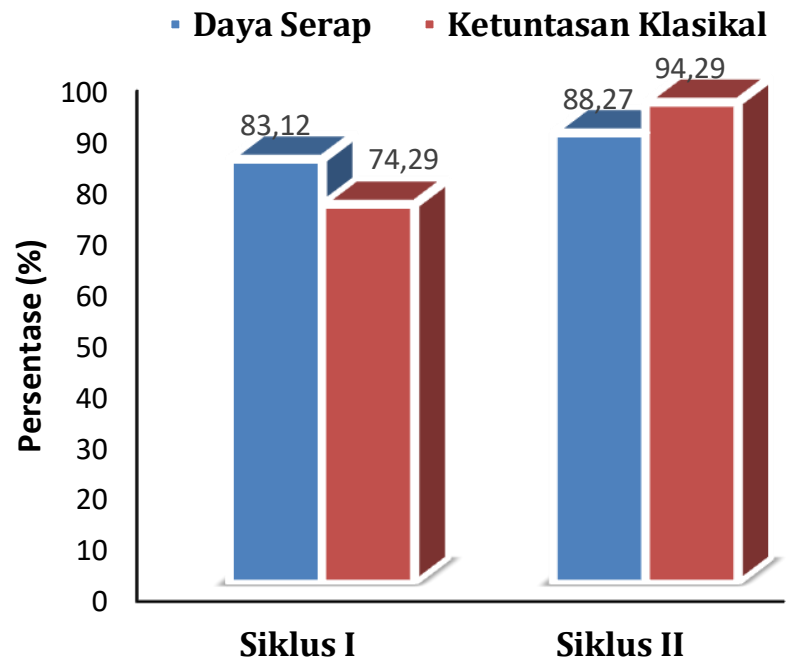

\section{Gambar 4. Perbandingan daya serap mahasiswa pada hasil belajar kognitif Siklus I} dan Siklus II

Berdasarkan data sebelum PTK dapat dijelaskan bahwa rata-rata daya serap nilai kognitif siswa yaitu 70,6 (kategori kurang). Rendahnya hasil belajar kognitif mahasiswa karena dosen belum menggunakan model yang tepat dalam proses pembelajaran, sehingga peserta didik cenderung bosan mengikuti kegiatan belajar mengajar, hal ini sesuai dengan pendapat Trianto, (2013), yang menjelaskan bahwa model-model pembelajaran inovatif, progresif, dan 
kontekstual merupakan konsep belajar yang membantu guru mengaitkan antara materi yang diajarkan dan situasi dunia nyata siswa, dan mendorong siswa membuat hubungan antara pengetahuan yang dimilikinya dan penerapannya dalam kehidupan mereka sebagai anggota keluarga dan masyarakat. Dengan konsep itu, hasil pembelajaran diharapkan lebih bermakna bagi siswa.

Pada nilai kognitif siklus I dan II yang diperoleh dari nilai kuis dan Tes Siklus I, rata-rata daya serap mahasiswa siklus I yaitu 83,12\% (kategori baik) karena pada saat siklus I mahasiswa belum terlalu memahami pembelajaran berdasarkan masalah dan belum terbiasa belajar dalam kelompok, hal ini mengakibatkan banyak mahasiswa yang belum mencapai niali KKM yaitu 75 . Nilai kognitif siklus II meningkat menjadi 88,27 (kategori baik) disebabkan mahasiswa sudah memahami pembelajaran berdasarkan masalah sehingga mahasiswa termotivasi untuk aktif berdiskusi dalam memecahkan permasalahan dan bekerja sama dalam kelompoknya. Hal ini sesuai dengan pendapat Trianto, (2013) model pengajaran berdasarkan masalah memiliki keuntungan sebagai suatu model pembelajaran yaitu mendorong kerja sama dalam menyelesaikan tugas, memiliki unsur-unsur belajar yang bisa mendorong pengamatan dan dialog dengan orang lain sehingga secara bertahap siswa dapat memahami peran penting aktivitas mental dan belajar yang terjadi di luar sekolah, melibatkan siswa dalam penyelidikan pilihan sendiri, yang memungkinkan siswa mengintarpretasikan dan menjelaskan fenomena nyata dan membangun pemahamannya tentang fenomena tersebut, membantu siswa menjadi pembelajar yang mandiri dan otonom.

Ketuntasan klasikal pada penilaian hasil belajar kognitif sebelum PTK 40\% (tidak tuntas) dan ketuntasan individu sebanyak 14 mahasiswa. Hal ini terjadi karena dosen hanya menggunakan metode pembelajaran konvensional (ceramah), dan lemahnya sikap ilmiah mahasiswa. Pada penilaian kognitif siklus I ketuntasan klasikal menjadi 74,29\% (tidak tuntas) dengan ketuntasan individu sebanyak 26 mahasiswa. Hal ini terjadi karena pada saat proses pembelajaran dosen sudah meng-gunakan pembelajaran berdasarkan masalah, dimana model pembelajaran ini membiasakan mahasiswa belajar ber-diskusi bersama teman kelompoknya dan lebih termotivasi untuk belajar. Selanjutnya pada siklus II ketuntasan klasikal menjadi 94,29\% (tuntas) dengan ketuntasan individu 33 siswa. Berdasarkan ketercapaian ketuntasan minimal secara klasikal yaitu $80 \%$, maka dapat disimpulkan bahwa terdapat perubahan hasil belajar siswa ke arahyang lebih baik. Sehingga dapat dikatakan penerapan model pembelajaran problem based learning (PBL) dapat meningkatkan hasil belajar kognitif mahasiswa.

Hal ini sejalan dengan yang dikemukakan Tan (dalam Rusman, 2013) yang menyatakan guru mempunyai peran aktif dalam menentukan permasalahan dan tahap-tahap pemecahannya. Rosmarita, (2010) menyatakan pembelajaran problem based learning adalah pendekatan pengajaran yang memberikan tantangan bagi siswa untuk mencari solusi dari permasalahan dunia nyata (terbuka) secara individu maupun kelompok. PBL membuat siswa mengembangkan keterampilan menjadi pembelajar mandiri. Permasalahan-permasalahan dipilah untuk menggali keingintahuan alami dengan cara menghubungkan pembelajaran dengan kehidupan sehari-hari siswa, serta menekankan pada penggunaan keterampilan berpikir analistis dan kritis

Peningkatan hasil belajar kognitif disebabkan karena siswa mulai terlibat aktif dalam pembelajaran serta tidak terlepas dari penggunaan model yang digunakan yaitu pembelajaran berdasarkan masalah, sehingga mahasiswa lebih mudah belajar dan berdiskusi bersama teman kelompoknya dan membantu mahasiswa untuk mempermudah dalam menjawab pertanyaan yang diajukan oleh dosen. Meningkatnya hasil belajar kognitif mahasiswa tidak terlepas dari sikap ilmiah yang dimiliki oleh mahasiswa. Semakin tinggi sikap ilmiah yang dimiliki oleh mahasiswa, maka semakin bagus pula hasil belajar kognitif mahasiswa. Sumiati \& Asra, (2007) menyatakan bahwa keberhasilan belajar pemecahan masalah memiliki transfer yang cukup tinggi, serta memiliki tingkat retensi yaitu dapat diingat dalam jangka waktu lama oleh siswa. 
Oleh karena itu, hasil belajar yang dicapai melalui bentuk belajar pemecahan masalah lebih tinggi nilai kemanfaatanya dibandingkan dengan belajar melalui proses pembelajaran yang berlangsung dengan penyajian materi pembelajaran sebagaimana terjadi dalam proses pembelajaran konvensional. Lebih lanjut Syafi (dalam Selamet, 2017) mengatakan bahwa tujuan dari pengajaran berbasis masalah adalah membimbing siswa untuk mengembangkan ilmu pengetahuan dasar, memiliki ketrampilan memecahkan masalah dan pengarahan diri dalam belajar. Tujuan yang lain yaitu mengembangkan ketrampilan belajar dari kehidupan, menjadi kolaborator yang efektif dan merangsang tumbuhnya motivasi intrinsik. Chakravarti (dalam Handayani \& Suardana, 2015) mengungkapkan bahwa model pembelajaran berbasis masalah berpengaruh terhadap kemampuan pemecahan masalah konseptual siswa yang berimplikasi pada kedalaman pemahaman konsep siswa. Siswa yang memiliki pemahaman konsep yang mendalam akan mampu membentuk pengetahuannya sendiri.

Hal ini sesuai dengan paradigma pembelajaran konstruktivisme bahwa belajar aktif mengkontruksi pengetahuan dalam benaknya sendiri. Adanya pemahaman konsep yang baik akan berdampak positif dalam pembelajaran karena siswa dapat melakukan eksplorasi pengetahuan dimana saja. Nurtanto (dalam Aprilianti et al., 2018) menjelaskan bahwa hubungan antara teori dan praktik bahwa dalam lingkungan PBL siswa terlibat aktif bekerja sesuai dengan tugas dan kegiatan otentik sesuai lingkungan dimana mereka akan menggunakannya atau bekerja. Fokusnya adalah siswa mengkonstruk pengetahuan mereka sendiri dalam konteks yang mirip dengan konteks dimana akan menerapkan pengetahuan itu. Sehingga, PBL mengkonstruksi pengetahuan dan mengaplikasikannya dalam keterampilan.

Kecerdasan intelektual dengan kecerdasan emosional membentuk kemampuan yang diperlukan siswa, untuk menghadapi suatu pekerjaan yang memerlukan ketekunan dan profesional, yang pada gilirannya dapat membantu belajar lebih jauh dalam kehidupan sesungguhnya (Rustaman, 2007). Hal ini dapat dilihat pada saat siswa berani dalam mempresentasikan hasil karya kelompok dan mempertimbangkan hasil yang disampaikan. Siswa sopan dalam menyampaikan pendapat saat diskusi, memperhatikan kesantunan dan memperlihatkan keilmiahan, serta terbuka terhadap pendapat orang lain.

\section{SIMPULAN}

Berdasarkan hasil analisis terhadap hasil penelitian, diperoleh bahwa penerapan model pembelajaran problem based learning (PBL) pada mata kuliah ekologi tumbuhan dapat meningkatkan sikap ilmiah mahasiswa Program Studi Pendidikan Biologi FKIP Universitas Islam Riau kelas 4D sebesar 15,97\% dimana rata-rata sikap ilmiah mahasiswa pada siklus I sebesar 74,37\% dengan kategori baik dan pada siklus 2 sebesar 90,34\% dengan kategori sangat baik. Selain itu, penerapan model pembelajaran problem based learning pada mata kuliah ekologi tumbuhan juga dapat meningkatkan daya serap mahasiswa Program Studi Pendidikan Biologi FKIP Universitas Islam Riau kelas 4D sebesar 5,5\% dimana rata-rata daya serap pada siklus I sebesar 83,12\% dengan kategori baik dan pada siklus 2 sebesar 88,27\% dengan kategori baik. Ketuntasan klasikal mengalami peningkatan sebesar 20\% dimana ketuntasan klasikal siklus I sebesar 74,29\% dan ketuntasan klasikal siklus 2 sebesar 94,29\%. Berdasarkan hal tersebut maka dapat disimpulkan bahwa penerapan model pembelajaran problem based learning dapat meningkatkan sikap ilmiah dan hasil belajar kognitif mahasiswa mahasiswa Program Studi Pendidikan Biologi FKIP Universitas Islam Riau kelas 4D pada mata kuliah ekologi tumbuhan. Saran untuk penelitian lebih lanjut adalah dengan melakukan penelitian tentang penerapan model pembelajaran problem based learning pada materi atau mata kuliah lainnya. 


\section{REFERENSI}

Aprilianti, L., Irawati, S., \& Kasrina, K. (2018). Peningkatan Sikap Ilmiah dan Hasil Belajar Siswa dengan Model Problem Based Learning. Diklabio: Jurnal Pendidikan dan Pembelajaran Biologi, 2(1), 58-67.

Arikunto, S. (2012). Penelitian Tindakan Kelas. Jakarta: Bumi Aksara.

Arsyad, A. (2013). Media Pembelajaran. Jakarta: PT. Raja Grafindo Persada.

Sumiati \& Asra. (2007). Model Pembelajaran. Bandung: CV. Wacana Prima.

Hamdani. (2011). Strategi Belajar Mengajar. Bandung: CV Pustaka Setia.

Handayani, I., \& Suardana, M. (2015). Komparasi Peningkatan Pemahaman Konsep dan Sikap Ilmiah Siswa SMA yang Dibelajarkan Dengan Model Pembelajaran Problem Based Learning dan Project Based Learning. Jurnal Pendidikan Dan Pembelajaran IPA Indonesia, 5(1), 1-12.

Mulyasa, E. (2006). Kurikulum Berbasis Kompetensi. Bandung: PT. Remaja Rosdakarya.

Rosmarita. (2010). Penerapan Pembelajaran Berdasarkan Masalab Terbadap Hasil Belajar Biologi Siswa Kelas X4 SMAN 2 Siak Hulu Tabun Ajaran 2009/2010. Skripsi Program Studi Pendidikan Biologi - FKIP-UIR. Pekanbaru.

Rusman. (2013). Model-model Pembelajaran. Jakarta: Rajawali Pers.

Rustaman, N. (2007). Strategi Pembelajaran Biologi. Jakarta: Universitas Terbuka.

Sardiman. (2012). Interaksi dan Motivasi Belajar-Mengajar. Jakarta: PT. Raja Grafindo Persada.

Selamet. (2017). Penerapan Model Pembelajaran Problem Based Learning (PBL) Untuk Meningkatkan Sikap Ilmiah Siswa Dan Hasil Belajar Kognitif Biologi Siswa Kelas X3 SMA Negeri 14 Pekanbaru 2015/2016. Jurnal Pendidikan Matematika Tambusai, 5(3), 1-14.

Slameto. (2010). Belajar dan Faktor-faktor yang Mempengarubi. Jakarta: Rineka Cipta.

Israfiddin, I., Gani, A., \& Saminan, S. (2016). Penerapan Model Problem Based Learning Untuk Meningkatkan Sikap Ilmiah Dan Hasil Belajar Peserta Didik Pada Materi Gerak Di SMP Negeri 2 Delima. Jurnal Pendidikan Sains Indonesia (Indonesian Journal of Science Education), $4(1)$.

Sobur. (2003). Psikologi Umum. Bandung: Pustaka Setia.

Ismiani, S., Syukri, S., \& Wahyudiati, D. (2017). Pengaruh Penerapan Metode Problem Based Learning Terhadap Sikap Ilmiah dan Hasil Belajar Biologi Siswa Kelas VII MTs NW 01 Kembang Kerang. Biota, 10(1), 104-113.

Susanti, P. D. A. (2018). Peningkatan Hasil Belajar IPA Melalui Model Pembelajaran Berbasis Masalah ( Problem Based Learning) Pada Siswa Kelas V SDN Purwasari III Kabupaten Karawang. Prosiding Seminar dan Diskusi Nasional Pendidikan Dasar, 495-500.

Trianto. (2013). Mendesain Model Pembelajaran Inovatif - Progresif. Jakarta: Kencana.

Undang-Undang Republik Indonesia Nomor 20. 2003. Sistem Pendidikan Nasional. Bandung: Citra Umbara.

Usman, U. (2010). Menjadi Guru Profesional. Bandung: PT Remaja Rosdakarya. 